\title{
Highly productive forage legume stands show no positive biodiversity effect on yield and $\mathbf{N}_{\mathbf{2}}$-fixation
}

\author{
Nawa Raj Dhamala • Jørgen Eriksen • \\ Georg Carlsson • Karen Søegaard • Jim Rasmussen
}

Received: 15 November 2016/Accepted: 4 April 2017 /Published online: 25 April 2017

(C) Springer International Publishing Switzerland 2017

\begin{abstract}
Background and aims While $\mathrm{N}_{2}$-fixation in diversified grasslands including forage legumes and non-legumes has been widely studied, $\mathrm{N}_{2}$-fixation in swards containing only forage legumes remains unclear. In this study, we investigated $\mathrm{N}_{2}$-fixation in pure stands and mixtures of three forage legumes.

Methodology $\mathrm{N}_{2}$-fixation, dry matter (DM) and nitrogen $(\mathrm{N})$ yields were quantified in a field experiment for red clover (Trifolium pratense L.), white clover (Trifolium repens L.) and lucerne (Medicago sativa L.) pure stands and mixtures using the isotope dilution method.

Results All three forage legume species derived most (around $85 \%$ ) of their $\mathrm{N}$ from atmospheric $\mathrm{N}_{2}$-fixation (\%Ndfa). However, no positive effect of species diversity was found in any of the mixtures. Species composition of the forage legume mixtures affected the amount of $\mathrm{N}$ from $\mathrm{N}_{2}$-fixation by affecting DM production and
\end{abstract}

Responsible Editor: Euan K. James.

Electronic supplementary material The online version of this article (doi:10.1007/s11104-017-3249-2) contains supplementary material, which is available to authorized users.

N. R. Dhamala $(\bowtie) \cdot$ J. Eriksen $\cdot$ K. Søegaard

J. Rasmussen

Department of Agroecology, Aarhus University, PO Box 50,

8830 Tjele, Denmark

e-mail: nawar.dhamala@agro.au.dk

G. Carlsson

Department of Biosystems and Technology, Swedish University of Agricultural Sciences, PO Box 103, 23053 Alnarp, Sweden
$\mathrm{N}$ accumulation of the species, where the seasonal amount of $\mathrm{N}_{2}$-fixation ranged from 370 to $500 \mathrm{~kg} \mathrm{~N}$ $\mathrm{ha}^{-1}$; which was highest in the presence of red clover. Conclusions We found that mixtures of the three forage legumes were highly productive, but did not show positive advantages compared to the red clover pure stands in terms of DM, $\mathrm{N}$ yield and \% Ndfa.

Keywords Grassland · Forage legume mixture · Percentage of $\mathrm{N}$ derived from atmosphere $(\% \mathrm{Ndfa}) \cdot \mathrm{N}$ yield

\section{Introduction}

The EU is nearly $30 \%$ self-sufficient in protein feed (Bouxin 2014), and there is an increasing demand for new homegrown sources of protein in the EU as alternatives to the import of soybean meal for livestock production. Nitrogen $(\mathrm{N})$ is one of the most limiting crop nutrients, and to produce the required protein sources from crops requires large inputs of $\mathrm{N}$. However, the efficiency of applied $\mathrm{N}$ resources is often low and such resources carry the risk of several environmental, economic and agronomic problems (Fowler et al. 2013). Hence, there is societal need to produce large amounts of plant protein without $\mathrm{N}$ fertilization or with more efficient use of available $\mathrm{N}$ resources. Compared to cropping systems containing only annual crops, grassland-based cropping systems that contain perennial legume-grass leys have shown more ecosystem benefits such as enhanced soil $\mathrm{C}$ and $\mathrm{N}$ 
sequestration, soil organic matter, soil fertility and biodiversity, reduced greenhouse gas emission and improved possibility to use marginal land for biomass prouduction (Tilman et al. 2006; Glover et al. 2010; Carlsson et al. 2017). In this context, forage legumes have the potential to produce $\mathrm{N}$-rich plant biomass with no inputs of $\mathrm{N}$ fertilizer.

Forage legumes are widely used in agriculture as a valuable means of supplying protein-rich feed (Lüscher et al. 2014) and maintaining soil $\mathrm{N}$ fertility and plant productivity (Anglade et al. 2015). Forage legumes in cropping systems introduce atmospheric $\mathrm{N}_{2}$ to the soil $\mathrm{N}$ pool through the process of biological $\mathrm{N}_{2}$-fixation and improve the $\mathrm{N}$ supply to companion non-legume species (Fustec et al. 2010; Pirhofer-Walzl et al. 2012) and subsequent crops in the rotation (Eriksen et al. 2008; Rasmussen et al. 2012). However, multiple studies have reported wide spatial and temporal variations in legume $\mathrm{N}_{2}$-fixation and contribution to soil $\mathrm{N}$ fertility (e.g. Carlsson and Huss-Danell 2003; Lüscher et al. 2014; Anglade et al. 2015). $\mathrm{N}_{2}$-fixation is the result of internal and external factors such as legume species and genotype, their interaction with the environment, management practices such as cutting, grazing and fertilization, and plant species diversity and composition (Carlsson and Huss-Danell 2003; Carlsson et al. 2009; Rasmussen et al. 2012).

Numerous studies on $\mathrm{N}_{2}$-fixation have shown that plant species diversity associating forage legumes with non-legumes in grasslands are some of the most efficient management factors that can be applied to increase legume reliance on $\mathrm{N}_{2}$-fixation (e. g. Carlsson and Huss-Danell 2003; Carlsson et al. 2009; Nyfeler et al. 2011). The studies suggest that $\mathrm{N}_{2}$-fixation is regulated by legume competition for available soil $\mathrm{N}$, defined as the gap between $\mathrm{N}$ availability in the soil and the $\mathrm{N}$ demand of the plant species in the mixtures, where nonlegume species compete for the available soil $\mathrm{N}$ forcing the legume species to acquire more $\mathrm{N}$ from biological $\mathrm{N}_{2}$-fixation.

To date, the $\mathrm{N}$ dynamics in diversified grasslands with forage legume and forage grasses have been extensively studied. The dynamics of $\mathrm{N}_{2}$-fixation in swards including only forage legume species remain poorly understood. In this new experiment, we investigated how each of the three forage legume species: red clover (RC; Trifolium pratense L.), white clover (WC;
Trifolium repens L.) and lucerne (LU; Medicago sativa L.) in a sward influence the growth, $\mathrm{N}_{2}$-fixation and $\mathrm{N}$ acquisition of the other legumes in the mixture.

These three forage legumes are widely cultivated and commercially important forage legumes across the globe (Phelan et al. 2015) and are potential biological $\mathrm{N}_{2}$-fixers in temperate grasslands (Carlsson and Huss-Danell 2003; Rasmussen et al. 2012). They differ in several key traits that are likely to influence growth, biomass production and $\mathrm{N}$ dynamics when included in species mixtures. In contrast to the deep tap root systems and large erect shoots of RC and LU, WC has clonal or stoloniferous and shallow adventitious root systems and higher shoot biomass. WC also forms leaves from stem faster than $\mathrm{RC}$ and is more resistant to frequent cutting (Black et al. 2009). Regarding canopy structure (leaf position and angle) and light interception, WC has horizontal leaves, which favors more light interception at the top of the canopy, while RC has greater distribution of the leaf area and light interception in the intermediate layer of the canopy (Black et al. 2009). When included in the species mixtures, $\mathrm{RC}$ is more competitive to grass than $\mathrm{LU}$ and WC (Black et al. 2009; Elgersma and Søegaard 2016). The three species also differ in their patterns of $\mathrm{N}$ uptake from the soil, of build-up and utilization of the $\mathrm{N}$ reserve in roots and in their ability to compete for recycled N. LU has shown ability to assimilate $\mathrm{N}$ from deep soil layers (Kelner et al. 1997), WC with their shallow roots take up $\mathrm{N}$ from upper soil layers (Rasmussen et al. 2013; Younie 2012). RC and LU build-up and remobilize carbohydrates and $\mathrm{N}$ stored in their large tap root system for shoot growth (Black et al. 2009; Barber et al. 1996). Moreover, they differ in their ability to fix atmospheric $\mathrm{N}_{2}$, to transfer and rhizodeposit fixed $\mathrm{N}$, and to receive $\mathrm{N}$ transferred from companion species as well as re-uptake of rhizodeposited N. RC and LU have shown to fix higher amount of $\mathrm{N}_{2}$ than WC (e.g. Rasmussen et al. 2012), whereas RC has been found to reach higher rate of transfer of fixed $\mathrm{N}$ to the companion species than RC and LU (HøghJensen and Schjoerring 2000; Louarn et al. 2015; Pirhofer-Walzl et al. 2012). RC has demonstrated better ability to absorb $\mathrm{N}$ transferred from companion spcies than WC (Pirhofer-Walzl et al. 2012), while low rates of $\mathrm{N}$ transfer have been found in LU, both as donor (Frankow-Lindberg and Dahlin 
2013; Louarn et al. 2015) and as receiver (PirhoferWalzl et al. 2012).

Varied above- and below-ground resource utilization and niche differentiation in space and time might occur between these species when grown in a mixture due to differences in plant architecture, and growth and $\mathrm{N}$ uptake patterns. In particular, the functional complementarity between forage legume species in a mixture might increase the utilization of soil $\mathrm{N}$ resources, making them stronger competitors for the available soil $\mathrm{N}$ in the rhizosphere, thereby increasing total plant production, $\mathrm{N}$ acquisition and the proportion of atmospheric $\mathrm{N}_{2}$-fixation in the mixture compared to the species grown in pure stands. Hence, exploration of plant production and $\mathrm{N}_{2}$-fixation in a mixture of forage legume species is expected to generate new knowledge towards achieving higher and more stable biomass and $\mathrm{N}$ yields. In addition, integration of sward containing forage legumes only in grassland is expected to increase the supply of protein without $\mathrm{N}$ fertilization. Thus, we conducted this study with the objectives of determining how the swards of forage legume species will affect: herbage yield, botanical composition, $\mathrm{N}$ yield and the percentage and amount of $\mathrm{N}$ derived from the atmosphere. The following hypotheses were tested: functional complementarity between the species with different above-and below-ground architecture increases 1) the herbage yield and $\mathrm{N}$ accumulation, and 2) the proportion of legume- $\mathrm{N}$ derived from the atmosphere in the forage legume mixtures compared to pure stands .

\section{Materials and methods}

\section{Experimental site}

This field experiment was conducted at Foulumgaard Experimental Station, Aarhus University, located in Central Jutland, Denmark $\left(09^{\circ} 34^{\circ} \mathrm{E}\right.$ and $56^{\circ} 29^{\circ}$ $\mathrm{N})$. The experimental field has grown cereals at least since 2010 prior to the establishment of the present experiment in 2014. The soil is loamy sand characterized as typic Hapludult comprising 7\% clay, $10 \%$ silt, $81 \%$ sand, and $1.7 \%$ carbon in the upper soil layer $(0-20 \mathrm{~cm})$ (Solati et al. 2017). Soil extractable $\mathrm{P}$ was $36 \mathrm{mg} \mathrm{kg}^{-1}$, soil exchangeable $\mathrm{K}$ was
$129 \mathrm{mg} \mathrm{kg}^{-1}$ and $\mathrm{pH}$ 5.9. The mean monthly air temperature during the experimental period between April and October 2015 ranged between 7 and $17{ }^{\circ} \mathrm{C}$, with July and August the warmest months. The monthly precipitation ranged from 21 to $117 \mathrm{~mm}$, where May, June, July and September were the wettest months (Fig. 1).

Experimental design and establishment of experimental plots

Ten different species mixtures, including pure stands, two- and three-species mixtures, were established in spring 2014 including commonly used cultivars of three forage legume species: red clover (Trifolium pratense $\mathrm{L}$. var. Suez), white clover (Trifolium repens L. var. Silvester) and lucerne (Medicago sativa L. var. Creno). The species were undersown in a spring barley cover crop in a replacement design, with different proportions of the species in the mixture based on their seeding rates in pure stands, in plots measuring $1.5 \times 12 \mathrm{~m}$ and in four replicates. The seeding rates in pure stands were 10,10 and $20 \mathrm{~kg} \mathrm{ha}^{-1}$ for $\mathrm{WC}, \mathrm{RC}$ and $\mathrm{LU}$, respectively (Table 1). The LU seeds were inoculated with rhizobium (Nitragin Gold) before sowing. The spring barley crop was harvested at maturity and $\mathrm{N}_{2}$-fixation was determined in situ during the first production year over the growing season between April and October in 2015 using the ${ }^{15} \mathrm{~N}$ isotope dilution method as applied by Rasmussen et al. (2012). In this method, $\mathrm{N}_{2}$-fixation is measured by comparing the dilution of soil-derived ${ }^{15} \mathrm{~N}$ by atmospheric $\mathrm{N}_{2}$ in the $\mathrm{N}_{2}$-fixating plan to the ${ }^{15} \mathrm{~N}$ enrichment of plants that derived all their $\mathrm{N}$ from soil. The non-legume reference plants are thus assumed to reflect the ${ }^{15} \mathrm{~N}$ enrichment of legume derived $\mathrm{N}$ from soil (Unkovich et al. 2008; Carlsson and Huss-Danell 2014). At the onset of the growing season, during the second week of April, a subplot (dilution plot) measuring $1 \times 1 \mathrm{~m}$ was demarcated in each experimental plot and the soil was labeled with ammonium Sulphate $0.1 \mathrm{~g}$ $\mathrm{N} \mathrm{m}^{-2}\left({ }^{15} \mathrm{~N}\right.$ enriched to 98 atom\%) to artificially enrich the soil with ${ }^{15} \mathrm{~N}$ above the background natural ${ }^{15} \mathrm{~N}$ abundance.

\section{Plant sampling and analysis}

The shoot biomass in each subplot was manually sampled four times during the growing season in a $0.25 \mathrm{~m}^{2}$ area at a stubble height of $5 \mathrm{~cm}$, following 
Fig. 1 Monthly precipitation and mean monthly air temperature during the experimental period from April to October in 2015 measured at a climate station near the experimental field

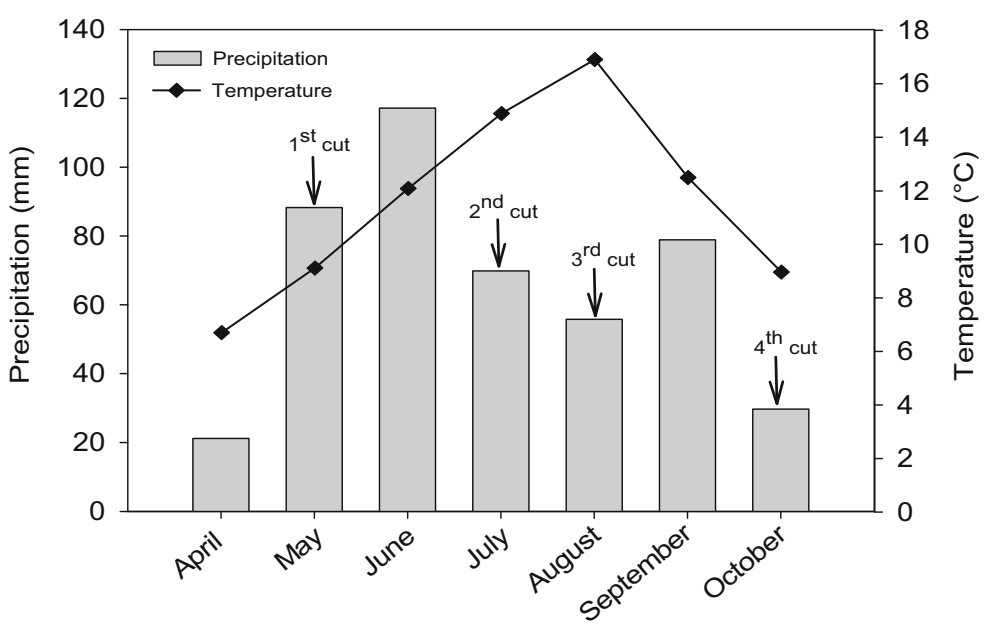

common agricultural practice in cut grassland. The first sampling was done on 22 May, the second on 1 July, the third on 17 August and the last on 5 October. The plant samples were manually sorted into individual species and weeds, air-dried at $80{ }^{\circ} \mathrm{C}$ for $24 \mathrm{~h}$ and dry matter (DM) weight was recorded. The dried samples were milled, subsampled and ball-milled into a fine powder, packed into small tin capsules and analyzed for total $\mathrm{N}$ concentration and atom $\%{ }^{15} \mathrm{~N}$ at UC Davis Stable Isotope Facility, University of California, USA, on an ANCA-SL Elemental Analyzer coupled to a 20-20 Mass Spectrometer using the Dumas dry-combustion method.
The $\mathrm{N}$ yield in each plot was determined as a product of shoot DM yield and $\mathrm{N}$ concentration in each species in the harvested biomass.

\section{Calculations}

The $\mathrm{N}_{2}$-fixation was quantified based on excess atom $\%{ }^{15} \mathrm{~N}$ in legumes and non-legumes using the weed species (representing both grasses and dicotyledon weed species) growing together with the legume species as reference plants (Carlsson and Huss-Danell 2014), using pooled samples of different weed species to avoid potential bias

Table 1 Composition of seed mixtures (percentage is based on each species seeding rate in pure stand)

\begin{tabular}{|c|c|c|c|c|c|c|c|}
\hline \multirow[t]{2}{*}{ Seed mixtures } & & \multicolumn{3}{|c|}{ Percentage of seed in the mixture $(\%)$} & \multicolumn{3}{|c|}{ Seeding rate $\left(\mathrm{Kg} \mathrm{ha}^{-1}\right)$} \\
\hline & & $\mathrm{RC}$ & WC & LU & $\mathrm{RC}$ & WC & LU \\
\hline \multirow[t]{3}{*}{ Pure stands } & $\mathrm{RC}$ & 100 & & & 10 & & \\
\hline & WC & & 100 & & & 10 & \\
\hline & LU & & & 100 & & & 20 \\
\hline \multirow[t]{3}{*}{ Two species } & $\mathrm{RC}+\mathrm{WC}$ & 50 & 50 & & 5 & 5 & \\
\hline & $\mathrm{WC}+\mathrm{LU}$ & & 50 & 50 & & 5 & 10 \\
\hline & $\mathrm{RC}+\mathrm{LU}$ & 50 & & 50 & 5 & & 10 \\
\hline \multirow[t]{4}{*}{ Three species } & $80 \mathrm{RC}+\mathrm{WC}+\mathrm{LU}$ & 80 & 10 & 10 & 8 & 1 & 2 \\
\hline & $\mathrm{RC}+80 \mathrm{WC}+\mathrm{LU}$ & 10 & 80 & 10 & 1 & 8 & 2 \\
\hline & $\mathrm{RC}+\mathrm{WC}+80 \mathrm{LU}$ & 10 & 10 & 80 & 1 & 1 & 16 \\
\hline & $\mathrm{RC}+\mathrm{WC}+\mathrm{LU}$ & 33 & 33 & 33 & 3.3 & 3.3 & 6.6 \\
\hline
\end{tabular}

RC: Red clover, WC: White clover, LU: Lucerne 
caused by spatiotemporal unevenness in soil ${ }^{15} \mathrm{~N}$ enrichment (Carlsson et al. 2009; Unkovich et al. 2008). The percentage of $\mathrm{N}$ derived from the atmosphere (\%Ndfa) was calculated using the following equation (Chalk et al. 2016):

$\% \mathrm{Ndfa}=\left(1-\left(\right.\right.$ excess atom $\%{ }^{15} \mathrm{~N}$ legume $/$ excess atom $\%{ }^{15} \mathrm{~N}$ reference $\left.)\right) \times 100$

where, excess atom $\%{ }^{15} \mathrm{~N}$ was calculated by subtracting the background atom $\%{ }^{15} \mathrm{~N}$ (determined by analyzing ${ }^{15} \mathrm{~N}$ in legumes and weed species grown in unlabeled field plots adjacent to the ${ }^{15} \mathrm{~N}$-labeled plots) from the atom $\%{ }^{15} \mathrm{~N}$ determined in the corresponding species in ${ }^{15} \mathrm{~N}$-labeled subplots. The average background atom $\%{ }^{15} \mathrm{~N}$ was 0.3676 in non-legumes and 0.3663 in legumes, and did not vary significantly across cutting occasion or legume species. Then the amount of $\mathrm{N}_{2}$-fixation was expressed as a product of $\% \mathrm{Ndfa}$ and $\mathrm{N}$ accumulation for the respective legume species. In the mixtures containing two or three legume species, the average $\% \mathrm{Ndfa}$ for the whole mixture was estimated as the ratio of total amount of $\mathrm{N}_{2}$ fixed to the total $\mathrm{N}$ accumulated in shoots, and the seasonal $\% \mathrm{Ndfa}$ was estimated as the ratio of the total amount of $\mathrm{N}_{2}$-fixed over the growing season to the total amount of shoot $\mathrm{N}$ accumulated. The soil $\mathrm{N}$ uptake was estimated subtracting the amount of $\mathrm{N}_{2}$-fixation from the $\mathrm{N}$ accumulated in shoots.

The relative yield (RY) was calculated for each species as its DM yield in the mixture as a proportion of its DM yield in the pure stand, with relative yield total (RYT; the sum of RYs for all species included in the mixture) values higher than 1 indicating the presence of complementarity effects in the mixture (Hector 1998).

\section{Data analysis}

The data were analyzed using the open-source statistical program R (R Core Team 2016) (Version 3.1.1). A oneway analysis of variance (ANOVA) was used to determine the effect of sown species composition on each of the dependent variables: DM yield, $\mathrm{N}$ yield, atom $\%{ }^{15} \mathrm{~N}$, $\% \mathrm{Ndfa}$, amounts of $\mathrm{N}_{2}$-fixation, $\mathrm{N}$ uptake, $\mathrm{RY}$ and $\mathrm{RYT}$, and the effect of two fixed factors (species composition and individual species) was tested using two-way ANOVA. The effect of time of cut on DM yield, $\mathrm{N}$ yield, \%Ndfa and amount of $\mathrm{N}_{2}$-fixation was tested using the linear mixed model. In the model, the composition of sown species (fixed effect) and time of cut (repeated fixed effect) were independent variables and block was a random factor, where plots were nested in the blocks. The model was then tested using ANOVA. For all dependent variables, the tests for significant differences between the seed mixtures were made using least square means in the adjusted Tukey method. The probability limit for rejection of the hypothesis was set at the confidence level 0.95 (P 0.05). The correlations between different dependent variables were tested using Pearson's correlation coefficient. The data violating the assumption of normal distribution were generally logtransformed before analysis to achieve a normal distribution of residuals.

\section{Results}

The weather at the experimental site measured during the experimental period from April to early October, 2015 (Fig. 1) showed similar temperatures to the 30year average measured at the same experimental station, while the mean monthly precipitation was about $30 \%$ higher than the 30-year average.

Dry matter production and composition of the sward

The seasonal total DM yield of the mixtures ranged from 10.7 to $16 \mathrm{tha}^{-1}$, with significant effect of species composition $(p<0.001)$ (Fig. 2). RC produced the highest DM yield among the pure stand, all species mixtures containing $\mathrm{RC}$ produced higher than pure stands of WC and LU and the WC paired with LU (Fig. 2). However, there was no significant difference between the seed mixtures containing RC. Species composition and seeding density affected the DM production in WC and LU, with the higher DM yield in the pure stand followed by the two-species mixture and three-species mixture with their $80 \%$ seeding density. Weeds were most abundant in the pure stand of LU, which was significantly higher than in all other treatments and was strongly suppressed in the mixtures containing RC.

The proportions of total DM yield differed markedly between the species across all mixtures. RC was the most productive of the three species, and the proportion of RC in the total harvested biomass was always much higher than its relative proportion in the seed mixture 
Fig. 2 Whole season shoot dry matter (DM) yield of red clover, white clover, lucerne and weeds grown in the field. Values are mean $( \pm \mathrm{SE} ; n=4)$ measured at four cutting times during the 2015 growing season. Different letters indicate statistically significant differences between species composition at the 0.05 level. RC: Red clover, WC: White clover, LU: Lucerne and 80: percentage of total seeds in the mixture

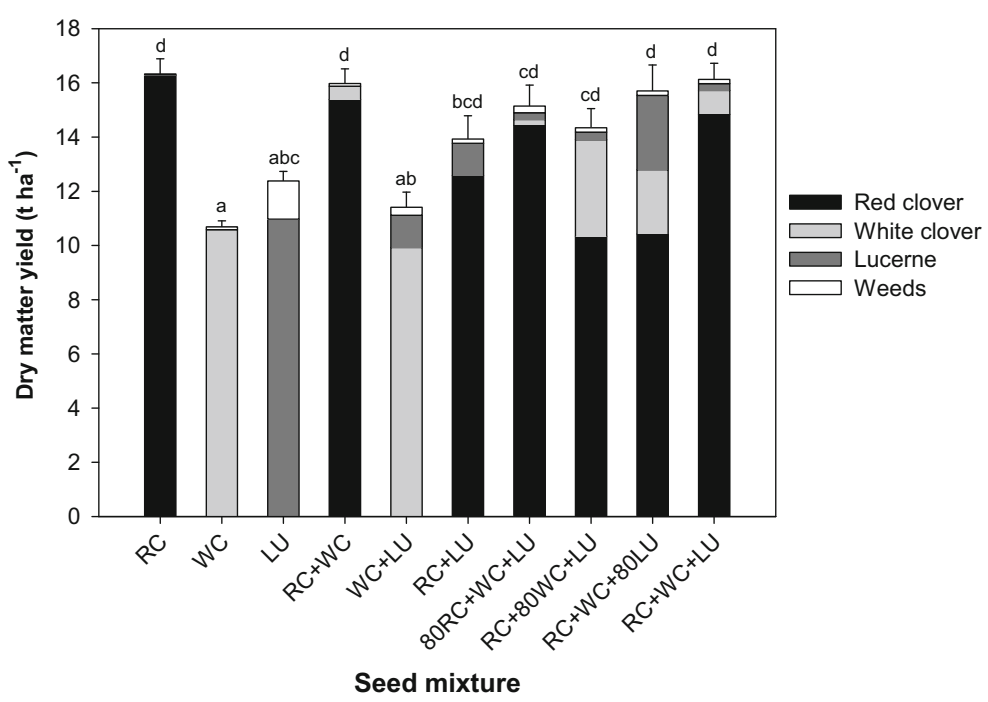

(Fig. 2). Hence, RC could be defined as the most competitive of the three legume species under the conditions of the present study. WC was always strongly suppressed by RC, but made up a higher proportion in the harvested biomass than its sown proportion in the twospecies mixture with LU, and could thus be defined as less competitive than RC but more competitive than LU. LU was always strongly suppressed in all mixtures.

The RYT values based on total seasonal DM yield were higher than 1 only in the WC + LU mixture (1.06) and the three-species mixture with $80 \%$ LU (1.2) (Supplementary Table 1). In two of the RC-dominated mixtures, RYT was lower than 1, i.e. 0.91 in $\mathrm{RC}+\mathrm{LU}$ and 0.93 in the three-species mixture with $80 \%$ RC.

$\mathrm{N}$ accumulation

The average total seasonal $\mathrm{N}$ accumulation ranged from 440 to $595 \mathrm{~kg} \mathrm{ha}^{-1}$, with significant differences between seed mixtures $(p<0.001)$. Since RC defined the DM yield of the mixtures, the total $\mathrm{N}$ accumulation of the mixtures mirrored the pattern of RC DM production, with considerable higher seasonal $\mathrm{N}$ accumulation in mixtures containing RC compared to pure stands of $\mathrm{WC}, \mathrm{LU}$ and the $\mathrm{WC}+\mathrm{LU}$ mixture, respectively (Table 3). WC accumulated from 10 to $440 \mathrm{~kg} \mathrm{~N}^{-1}$, with the largest amount in the pure stand followed by $\mathrm{WC}+\mathrm{LU}$ and RC + 80WC + LU. Similarly, N accumulation in LU ranged from 10 to $450 \mathrm{~kg} \mathrm{ha}^{-1}$ with the largest amount in the pure stand followed by $\mathrm{RC}+$ $\mathrm{WC}+80 \mathrm{LU}$ and $\mathrm{RC}+\mathrm{LU}$.
Proportions and amounts of $\mathrm{N}_{2}$-fixation

The values of atom $\%{ }^{15} \mathrm{~N}$ in forage legumes and reference species were substantially above the natural abundance, and differences between the ${ }^{15} \mathrm{~N}$ enrichment of legumes and reference species were sufficient to estimate the $\%$ Ndfa. The ${ }^{15} \mathrm{~N}$ enrichment was highest at the first cut and decreased from the second cut onwards. The excess atom $\%{ }^{15} \mathrm{~N}$ in the legumes ranged from 0.2087 to 3.5486 at the first cut and from 0.0718 to $0.9688,0.0221$ to 0.2687 and 0.0372 to 0.1679 at the second, third and fourth cuts, respectively (data not shown). The excess atom $\%{ }^{15} \mathrm{~N}$ in weed species did not show any significant difference between species composition treatments (Table 2), and the average weed excess atom $\%{ }^{15} \mathrm{~N}$ (used as reference plant values for the calculation of $\mathrm{N}_{2}$-fixation at each cut) was 3.9784 , $1.1790,0.3386$ and 0.2373 for the first, second, third and fourth cuts, respectively.

On a seasonal basis (Table 3), all the three forage legume species in the pure stand derived above $80 \%$ of their $\mathrm{N}$ from atmospheric $\mathrm{N}_{2}$-fixation (\% $\left.\mathrm{Ndfa}\right)$, which was similar for $\mathrm{WC}$ and $\mathrm{RC}$. The $\% \mathrm{Ndfa}$ in the pure stand of LU was significantly higher than in the pure stand of $\mathrm{WC}$ and $\mathrm{RC}$ and the mixture of $\mathrm{WC}+\mathrm{LU}$ $(p<0.01)$. In the two- and three-species mixtures, the $\%$ Ndfa in WC and RC was mostly above $80 \%$, irrespective of composition of seed mixtures, but tended to decrease in LU (Table 3). However, the \%Ndfa estimated in all three species was not affected by the composition of the seed mixture. Since RC dominated the 
Table 2 Excess atom $\%{ }^{15} \mathrm{~N}$ in shoots of reference plants (pooled samples of weed species). Values are mean $( \pm \mathrm{SE} ; n=4)$ measured at four cuts during the 2015 growing season. No significant difference between the treatments was found at any of the cuts

\begin{tabular}{llllll}
\hline Seed mixtures & & Cut 1 & Cut 2 & Cut 3 & Cut 4 \\
\hline Pure stand & RC & $4.484 \pm 1.250$ & $1.302 \pm 0.280$ & $0.333 \pm 0.043$ & $0.278 \pm 0.024$ \\
& WC & $3.458 \pm 0.986$ & $1.215 \pm 0.101$ & $0.219 \pm 0.044$ & $0.206 \pm 0.011$ \\
& LU & $2.830 \pm 0.920$ & $0.835 \pm 0.039$ & $0.253 \pm 0.006$ & $0.214 \pm 0.008$ \\
Two species & RC + WC & $5.632 \pm 0.568$ & $1.399 \pm 0.100$ & $0.428 \pm 0.065$ & $0.283 \pm 0.034$ \\
& WC + LU & $3.858 \pm 0.355$ & $1.419 \pm 0.143$ & $0.387 \pm 0.070$ & $0.162 \pm 0.001$ \\
& RC + LU & $3.645 \pm 1.107$ & $1.265 \pm 0.250$ & $0.328 \pm 0.035$ & $0.261 \pm 0.029$ \\
Three species & 80RC + WC + LU & $4.034 \pm 0.199$ & $1.274 \pm 0.127$ & $0.374 \pm 0.032$ & $0.253 \pm 0.028$ \\
& RC + 80WC + LU & $2.862 \pm 0.780$ & $0.857 \pm 0.068$ & $0.269 \pm 0.019$ & $0.200 \pm 0.012$ \\
& RC + WC + 80 LU & $3.742 \pm 0.383$ & $1.031 \pm 0.078$ & $0.351 \pm 0.060$ & $0.246 \pm 0.024$ \\
& RC+ WC + LU & $4.095 \pm 0.693$ & $1.106 \pm 0.288$ & $0.363 \pm 0.042$ & $0.222 \pm 0.016$ \\
\hline
\end{tabular}

$R C$ Red clover, $W C$ White clover, $L U$ Lucerne and 80: percentage of total seeds in the mixture

mixtures, the weighted $\% \mathrm{Ndfa}$ for the whole mixtures closely resembled the \%Ndfa in RC, which was consistently above $80 \%$ with no significant difference between the two- and three-species mixtures.

The measured \%Ndfa at each cut (Table 4) showed that RC and WC mostly derived above $80 \%$ of their $\mathrm{N}$ from fixation during the first three cuts. The $\% \mathrm{Ndfa}$ in LU tended to be higher in the pure stand than in mixtures, and this difference between LU pure stands and LU in mixtures was more pronounced than the corresponding differences between pure stands and mixtures in $\mathrm{RC}$ and WC. However, the species composition, in general, did not affect the \%Ndfa in either of the three species or the weighted average $\% \mathrm{Ndfa}$ for the whole mixture.

The \%Ndfa in RC and WC did not change with species composition, variation in $\mathrm{DM}$ production or botanical composition (Fig. 3). However, \%Ndfa in LU appeared to be positively influenced by biomass yield at low yield levels, i.e. up to around $1 \mathrm{t} \mathrm{DM}$ $\mathrm{ha}^{-1}$. At higher biomass yields, the $\%$ Ndfa tended to be more stable around or above $80 \%$ (Fig. 3).

The amount of $\mathrm{N}_{2}$-fixation varied between the mixtures and cuts, with a significant interaction effect $(p<0.001)$. The $\mathrm{N}_{2}$-fixation was generally higher in the pure RC stand and in the mixtures containing RC. The seasonal amount of $\mathrm{N}_{2}$-fixation in the mixtures ranged from 370 to $500 \mathrm{~kg} \mathrm{~N}$ ha $^{-1}$, with significant differences between the seed mixtures $(p<0.001)$ (Table 3). Since \%Ndfa was not affected by the composition of the seed mixture, the amount of $\mathrm{N}_{2}$ fixed in all three species was closely related to the $\mathrm{N}$ accumulation.
The pure stand of $\mathrm{RC}$, and the $\mathrm{WC}+\mathrm{RC}$ and $\mathrm{WC}+$ $\mathrm{RC}+80 \mathrm{LU}$ mixtures fixed amounts of $\mathrm{N}$ that were significantly higher than in the pure stands of WC, LU and the WC + LU mixture. Similarly, all the threespecies mixtures fixed significantly larger $\mathrm{N}$ amounts than the pure stand of WC.

When looking at each species, $\mathrm{RC}$ in the mixtures generally fixed as much $\mathrm{N}$ as in the pure stand, with the exception of the three-species mixture with the high seeding density of WC or LU. However, the seeding density influenced the $\mathrm{N}_{2}$-fixation in $\mathrm{WC}$ and $\mathrm{LU}$, affecting their proportion of total DM in the harvested biomass. On a seasonal basis, WC fixed more $\mathrm{N}$ when grown with LU in the two-species mixture, which was nearly similar to the WC in the pure stand. However, $\mathrm{N}_{2}$-fixation in LU was suppressed in the mixtures, irrespective of seeding density, with significantly lower amounts of $\mathrm{N}_{2}$-fixed compared to its pure stand (Table 3).

The seasonal soil $\mathrm{N}$ uptake was significantly lower in pure stand of LU $(p<0.01)$, but did not differ across the two-and three-species mixtures (Table 3 ).

\section{Discussion}

Plant growth and sward competition

In the present study, the pure RC stand and mixtures containing $\mathrm{RC}$ showed a yield advantage compared to pure stands of $\mathrm{WC}$ and $\mathrm{LU}$ and the $\mathrm{WC}+\mathrm{LU}$ mixture. However, there was no evidence of an effect of diversity 


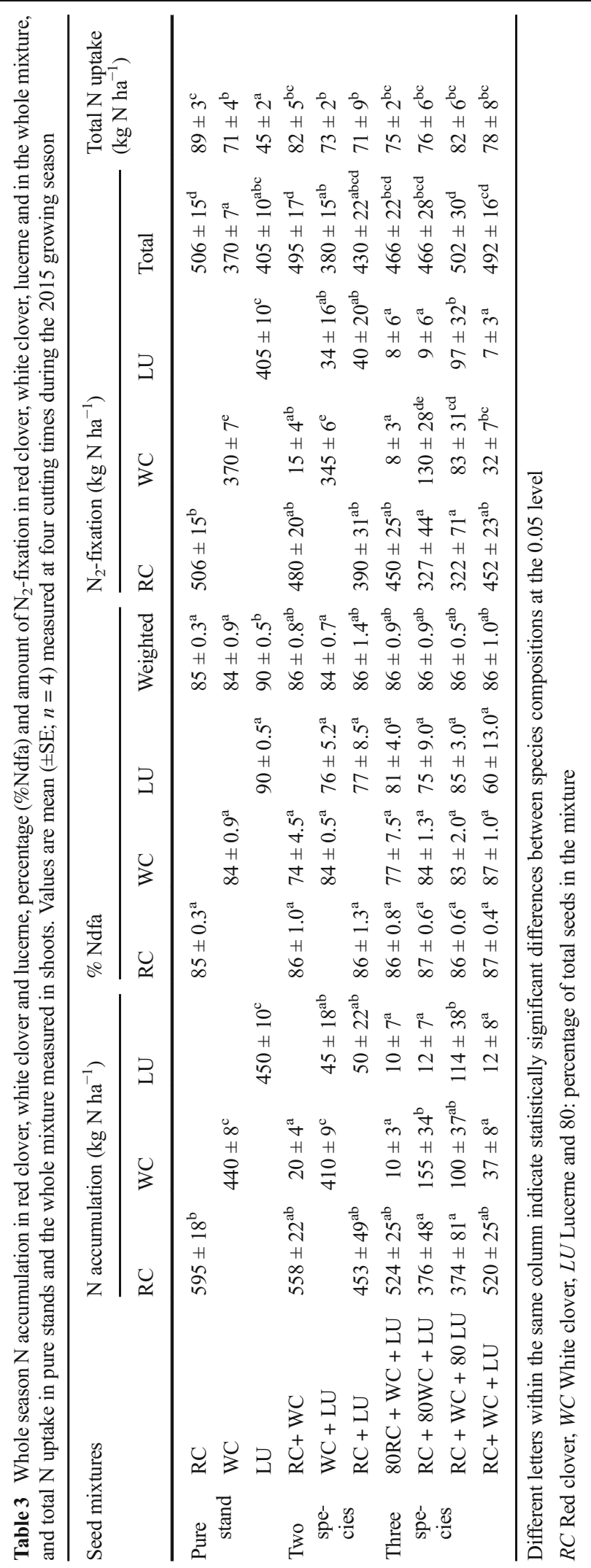




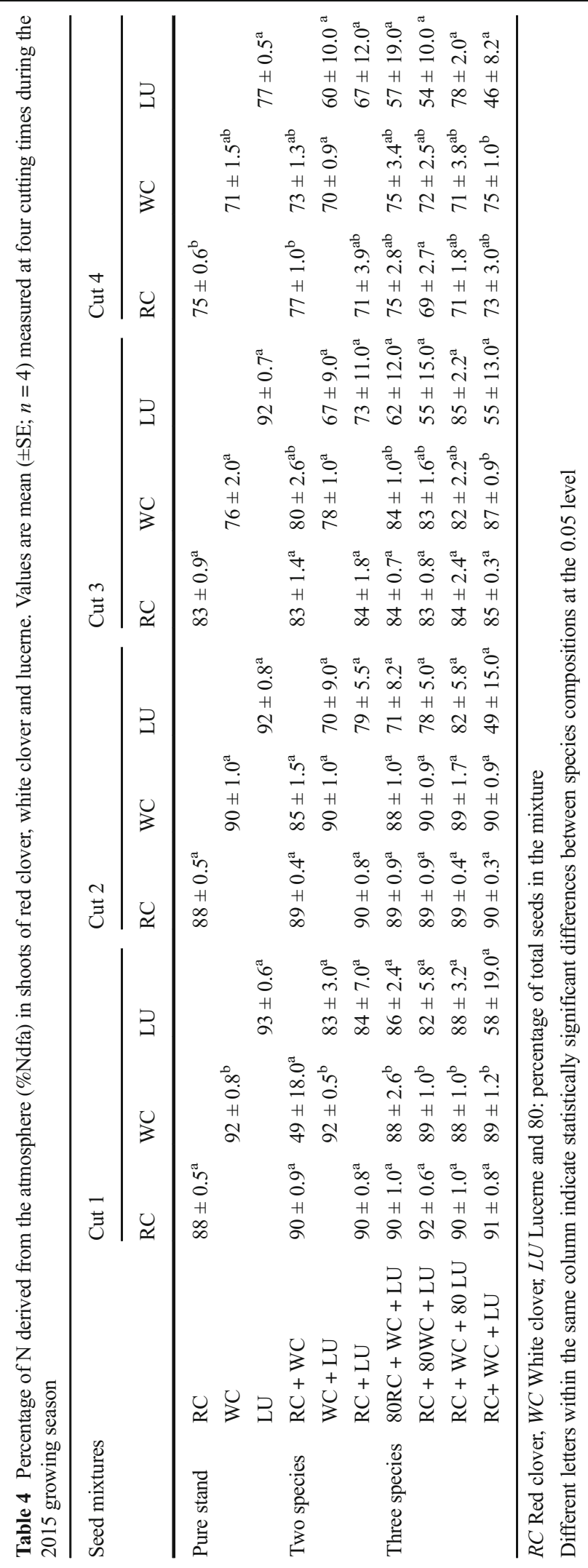



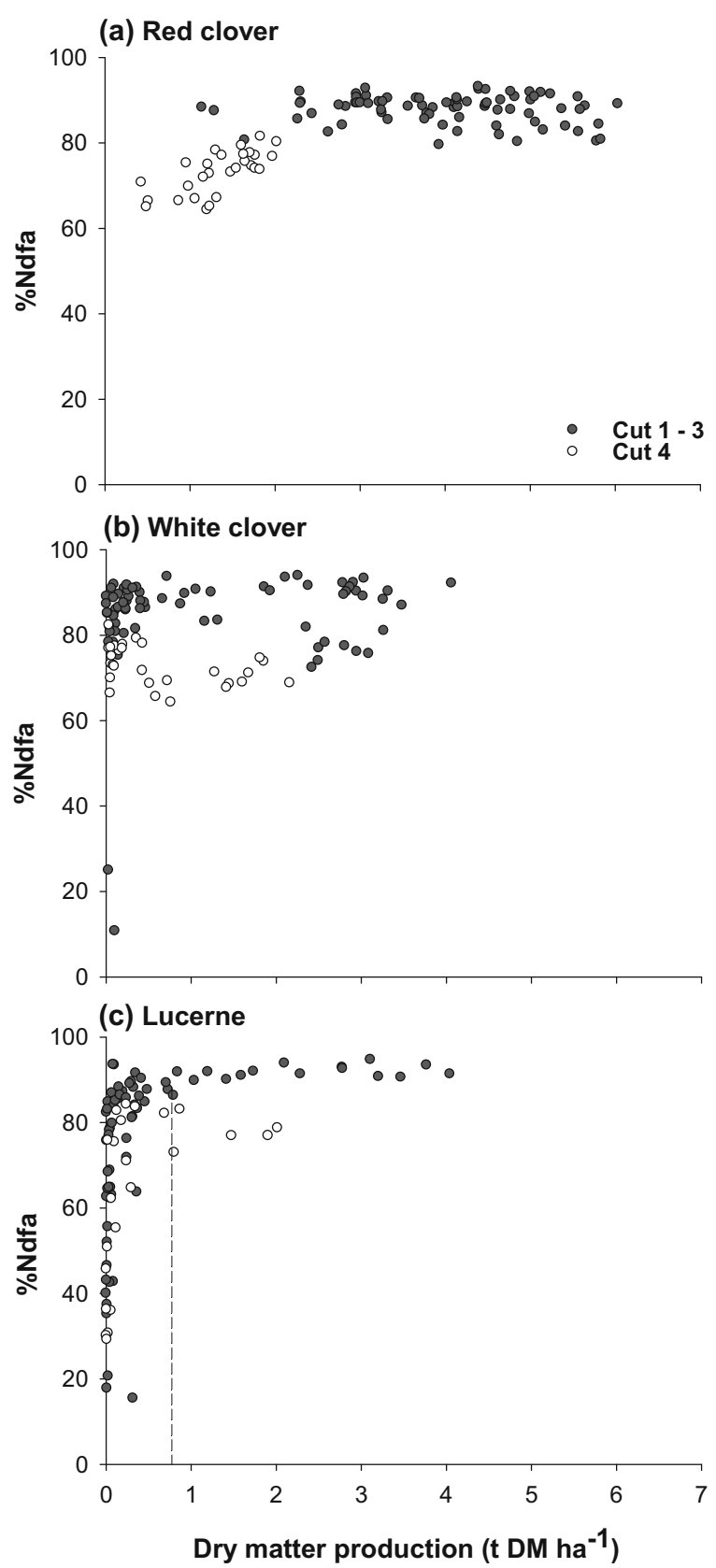

Fig. 3 Relationship between the dry matter production and percentage of $\mathrm{N}$ derived from atmosphere $(\% \mathrm{Ndfa})$ in the three forage legume species measured at four cutting times during the 2015 growing season. The dashed vertical line in c. Lucerne represent threshold line for positive association between LU dry matter production and $\% \mathrm{Ndfa}$

leading to transgressive over-yielding (Palmborg et al. 2005), since none of the mixtures were more productive in terms of biomass yield, $\mathrm{N}$ accumulation or $\mathrm{N}_{2}$-fixation than the highest-yielding pure stand (RC). One explanation for the lack of an over-yielding effect could be that we had no non-legume species in the mixture that would benefit from legume-fixed N (Dhamala et al. in press; Nyfeler et al. 2011) and increase the complementarity of $\mathrm{N}$ use in mixtures with the fertilizing function of legumes and the uptake of this $\mathrm{N}$ by non-legumes (Palmborg et al. 2005). Since the WC and LU were outcompeted in mixtures with $\mathrm{RC}$, another explanation for the lack of transgressive over-yielding could be a lack of evenness in the growth of the species in the mixture (Kirwan et al. 2007) or the lack of evenness in the resource partitioning among the species in the mixture (Roscher et al. 2008). In our study, the mixture with the most even biomass yield proportions of the three species, i.e. the three-species mixture with $80 \% \mathrm{LU}$, also had the highest RYT value (1.2). This observation supports previous findings that evenness of species proportions in mixtures enhances complementarity effects in resource use among the mixed species.

The total DM and $\mathrm{N}$ yields of the mixtures containing $\mathrm{RC}$ in the present experiment (i.e. without grass in the mixture) were comparable to previous studies of grasslegume mixtures at the same location (Elgersma and Søegaard 2016; Pirhofer-Walzl et al. 2012; Rasmussen et al. 2012) and higher or within the range of grassland production measured in various geographical regions in Europe (e. g. Anglade et al. 2015; Kirwan et al. 2007; Phelan et al. 2015). Thus, our study showed that when $\mathrm{RC}$ was present in the seed mixture, total $\mathrm{DM}$ and $\mathrm{N}$ yields were not compromised in the forage legume mixtures. Furthermore, the abundance of weeds was strongly suppressed in the pure stands of RC and WC as well as in the mixtures containing $\mathrm{RC}$ compared to the LU pure stand. This suggests that the mixtures containing competitive legumes attributed to lower weed invasion (Kirwan et al. 2007) and there was a high resource utilization efficiency of the sown species in the mixture (Sanderson et al. 2005).

We observed contrasting growth and competition between the three forage legume species in the mixture. $\mathrm{RC}$ consistently dominated in the mixtures irrespective of species composition and seeding densities of WC and LU; hence, RC defined the DM and $\mathrm{N}$ yields of the mixtures. This demonstrates the strong ability of RC to compete for above- and below-ground resources (Pirhofer-Walzl et al. 2012). We observed that RC was the most productive in the pure stand and always dominated in the mixture, with the RY value ranging from 0.63 to 0.94 and the RYT value below or near 1 in most 
of the mixtures, with the evidence that there was no complementarity between the species in the RCdominated mixtures for the resource utilization (Hector 1998). Canopy characteristics of the species in the mixture was found to play an important role for light interception for photosynthesis and thereby growth in the study by Black et al. (2009), and an explanation for the restrained growth of the WC and LU in our study could be that they were shaded by the vigorous upright growth of RC (Frame 2005) and therefore outcompeted for light. The poor light interception could have lowered the leaf/stem ratio and the photosynthetic activity in LU and WC. Thompson and Harper (1988) showed that many growth attributes such as stolon branching, petiole and internode lengths and number of branched and rooted nodes in WC are affected by canopy light interception (quality of radiation transmitted) under the canopies of different grass species. We observed that the proportions of WC and LU increased with later cuts, while the RC generally showed the opposite trend with a significantly lower DM yield at the fourth cut. A second explanation could be environmental factors in that the mean monthly air temperature during the growing season (Fig. 1) remained lower than the optimum growth temperature required for the three species, the better performance of RC could be potentially due to its ability to grow in a wider range of temperatures than WC and LU (Frame 2005). A third explanation for the poor growth, especially of LU, could be the preference of $\mathrm{LU}$ for a less frequent cutting regime than the four cuts per year applied in this study (Frame 2005; Wolf and Smith 1964). Our result indicate that the dominant species, $\mathrm{RC}$ in the present experiment, was the better able of the three to exploit the available resources.

Proportions of $\mathrm{N}$ derived from the atmosphere (\%Ndfa)

We observed that the three forage legume species relied mainly on $\mathrm{N}$ derived from atmospheric $\mathrm{N}_{2}$-fixation, regardless of whether they were grown in pure stand or in two- or three-species mixtures. Hence, our second hypothesis that the proportion of legume- $\mathrm{N}$ derived from the atmosphere would increase in mixtures compared with pure stands was not confirmed. Numerous studies on $\mathrm{N}_{2}$-fixation have demonstrated that the $\% \mathrm{Ndfa}$ is positively influenced by plant diversity in grasslands that are made up of a mixture of forage legumes and non-legumes due to non-legume competition for available soil N (e.g. Carlsson and Huss-Danell
2003; Nyfeler et al. 2011; Rasmussen et al. 2012). Carlsson et al. (2009) and Palmborg et al. (2005) further suggested that functional traits of the species in the mixture play a more important role for efficient $\mathrm{N}$ uptake and stimulatory effect on $\% \mathrm{Ndfa}$. In this light, previous studies have shown that forage legumes in swards containing non-legumes, especially grasses, often derive up to $90 \%$ or more of their $\mathrm{N}$ from atmospheric $\mathrm{N}_{2}$-fixation (Carlsson and Huss-Danell 2003; Rasmussen et al. 2012). The present study showed that the three studied forage legumes were equally good (or bad) competitors for soil N, i.e. that there was no difference between intra- and inter-specific competition for soil $\mathrm{N}$, indicating that legume-legume mixtures behave like pure stands of legumes in terms of soil $\mathrm{N}$ acquisition. Hence, the documented trait differences between the three studied legumes (see references in introduction) in above- and below-ground growth, dynamics in acquisition and use of different $\mathrm{N}$ sources and competitive ability did not influence their $\mathrm{N}_{2}$-fixation when grown together in mixture without non-legumes. Thus, in order to have a mixture effect on $\% \mathrm{Ndfa}$, the swards needs to contain non-legume species, which compete more efficiently for available soil $\mathrm{N}$ than the legumes.

The normally accepted regulation mechanism for $\% \mathrm{Ndfa}$ is the availability of soil $\mathrm{N}$, whereby a high $\mathrm{N}$ availability reduces $\% \mathrm{Ndfa}$ and a low $\mathrm{N}$ availability increases $\% \mathrm{Ndfa}$. It is possible that the consistently high $\%$ Ndfa in our study was a consequence of generally low levels of plant-available soil $\mathrm{N}$, since the field experiment was not fertilized, and that the legumes therefore relied to a large extent on $\mathrm{N}_{2}$-fixation for their $\mathrm{N}$ acquisition also when grown in pure stands. The lack of the expected effect of mixture could also be explained, at least in part, by complementary rooting patterns among the three forage legume species reducing the direct competition for plant-available soil N. LU has a relatively higher capacity to absorb $\mathrm{N}$ from deep soil layers (Kelner et al. 1997), whereas WC has been shown to assimilate nutrients more easily from the upper soil layers with the help of stoloniferous (creeping) roots (Younie 2012; Rasmussen et al. 2013). The large root system of RC may have given it more flexibility to explore the $\mathrm{N}$ from both upper and lower soil profiles. Furthermore, RC and LU accumulate and use their large root system as an $\mathrm{N}$ reserve, and that their shoot regrowth is mainly supported by the supply of $\mathrm{N}$ from roots (Barber et al. 1996; Black et al. 2009). Thus, LU and $\mathrm{RC}$, in the present experiment, could have built up 
more reserve $\mathrm{N}$ in their roots and therefore competed less with companion species for the available soil $\mathrm{N}$. Given the fairly large variation in the proportions of the three legumes across the mixtures, the finding that none of the three legumes seemed to be affected by competition for available soil $\mathrm{N}$ indicates that the legumes competed mainly for other resources, such as light, water and nutrients other than $\mathrm{N}$.

Previous studies have shown that all three forage legume species are net donors of $\mathrm{N}$ when in mixture with non-legume species. WC is a generous N-donor (Høgh-Jensen and Schjoerring 2000; Pirhofer-Walzl et al. 2012), but a poor receiver of the $\mathrm{N}$ transferred from companion species, while $\mathrm{RC}$ is an intermediate donor and a good receiver (Pirhofer-Walzl et al. 2012). LU has been shown to retain its plant $\mathrm{N}$ with a lower proportion being transferred (Frankow-Lindberg and Dahlin 2013; Louarn et al. 2015) and less fixed $\mathrm{N}$ being rhizodeposited (Louarn et al. 2015; Wichern et al. 2008 ), including a poorer ability to absorb the $\mathrm{N}$ transferred from companion species (Pirhofer-Walzl et al. 2012). Thus, we suggest an alternative regulation mechanism for $\% \mathrm{Ndfa}$ that the re-uptake by the legume of its $\mathrm{N}$ exudates may be regulating $\% \mathrm{Ndfa}$. Our result indicates that the legumes, especially RC, could access their $\mathrm{N}$ exudates due to the absence of non-legume competition for the legume-derived $\mathrm{N}$, as observed by the net transfer of $\mathrm{N}$ to companion species in mixtures with nonlegumes (e.g. Rasmussen et al. 2013; Dhamala et al. in press).

Interestingly, the \%Ndfa of LU showed a dependency on DM yield, which was not found for RC and WC. The LU, in general, had a relatively lower $\% \mathrm{Ndfa}$ than $\mathrm{RC}$ and $\mathrm{WC}$ in the mixtures, but this tended to be higher in the pure stand (Tables 2 and 3). Therefore, despite comparable levels of shoot yields of WC and LU, the \%Ndfa tended to be lower in LU than WC. The differences in \%Ndfa between the two species could partly be the result of differences in their pattern of $\mathrm{N}$ uptake. LU has been shown to compete more strongly for available soil $\mathrm{N}$ and act as both a source and sink for the recycled mineral N (Tomm et al. 1995). Therefore, LU in the present experiment when grown in mixtures must have extracted more $\mathrm{N}$ from the soil pool, resulting in less dependency on atmospheric $\mathrm{N}_{2}$-fixation when the DM yield of LU was low. In contrast, with a higher biomass production in pure stand, soil $\mathrm{N}$ might have become limited and LU had to increase its reliance on $\mathrm{N}_{2}$-fixation. Another possible explanation that the higher weed abundance in pure stand of LU may have led higher competition for the available $\mathrm{N}$, thereby reducing its access to soil $\mathrm{N}$ and stimulating a higher \%Ndfa in LU pure stand. Buildup and utilization of the $\mathrm{N}$ reserve in the roots may have been lower in WC because of a higher rate of transfer and rhizodepositon of fixed N (Pirhofer-Walzl et al. 2012; Louarn et al. 2015) and a fast turnover and $\mathrm{N}$ release from roots (Louarn et al. 2015). Hence, the dependency on $\mathrm{N}_{2}$-fixation was in general higher for WC than for LU. Furthermore, the lower \%Ndfa of LU at DM productions below $1 \mathrm{t} \mathrm{DM} \mathrm{ha}^{-1}$ could also be related to a higher metabolic cost of $\mathrm{N}_{2}$-fixation as the plants should be able to supply the necessary carbohydrates produced from photosynthesis for the $\mathrm{N}$ fixed from bacteria (Schulze 2004). This indicates that the growth of LU at low densities might have been limited by resources other than soil N (e.g. light, water, other nutrients) caused by competition from $\mathrm{RC}$ and WC. In summary, our result suggests that the three forage legume species varied in their competitiveness, including their $\mathrm{N}$ acquisition strategies, but that these differences did not cause significant variations in $\% \mathrm{Ndfa}$ when the studied legumes were grown together in different mixtures.

Variations in \%Ndfa estimates obtained with the ${ }^{15} \mathrm{~N}$ isotope dilution method might be confounded by spatiotemporal unevenness in soil ${ }^{15} \mathrm{~N}$ enrichment after the addition of ${ }^{15} \mathrm{~N}$-labelled fertilizer, as documented by Burchill et al. (2014). Such unevenness would undermine the assumption that the excess atom $\%{ }^{15} \mathrm{~N}$ in the sampled reference plants represents the ${ }^{15} \mathrm{~N}$ enrichment of soil $\mathrm{N}$ available to the legume, at least if the legume and the reference plant differ in their soil $\mathrm{N}$ uptake patterns. To avoid the risk of large bias caused by spatiotemporal variations in soil ${ }^{15} \mathrm{~N}$ enrichment, we followed the approach to use the average excess atom $\%$ ${ }^{15} \mathrm{~N}$ of several reference species (pooled samples of weeds, representing both grasses and dicotyledon species) as suggested by e.g. Carlsson et al. (2009), Jacot et al. (2000) and Unkovich et al. (2008). Furthermore, we avoid the risk of misinterpreting temporal variations in $\mathrm{N}_{2}$-fixation as we analyze effects of the different species compositions at each individual cutting occasion or on the seasonal mean value instead of analyzing temporal variations between cutting occasions. 
Amount of $\mathrm{N}_{2}$-fixation

In the present study, given the similar levels of \%Ndfa, the differences in $\mathrm{N}_{2}$-fixation among the species were mainly driven by the differences in DM production and $\mathrm{N}$ accumulation, as observed in previous investigations and documented in reviews (e.g. Anglade et al. 2015; Carlsson and Huss-Danell 2003; Nyfeler et al. 2011).

The seasonal amount of $\mathrm{N}$ fixed in the whole mixture $\left(370-500 \mathrm{~kg} \mathrm{ha}^{-1}\right)$ in the present experiment was higher than a previously reported range of $\mathrm{N}_{2}$-fixation (100$380 \mathrm{~kg} \mathrm{~N} \mathrm{ha}^{-1} \mathrm{yr}^{-1}$ ) in European grasslands (Lüscher et al. 2014). The fixed amount of $\mathrm{N}$ was comparable to the highest amount of $\mathrm{N}_{2}$-fixation recorded in $\mathrm{RC}$ (545 $\mathrm{kg} \mathrm{ha}^{-1}$ ) and LU (443 $\mathrm{kg} \mathrm{ha}^{-1}$ ) in Europe (Anglade et al. 2015), and the reported highest amounts of $\mathrm{N}_{2}$-fixation in WC (545 $\left.\mathrm{kg} \mathrm{ha}^{-1}\right), \mathrm{RC}\left(373 \mathrm{~kg} \mathrm{ha}^{-1}\right)$ and LU $\left(350 \mathrm{~kg} \mathrm{ha}^{-1}\right)$ in northern European grasslands (Carlsson and Huss-Danell 2003). Thus, the present organic temporary grassland demonstrated a high $\mathrm{N}$ input from $\mathrm{N}_{2}$-fixation. Since we did not observe any transgressive over-yielding, none of the mixtures in the present study fixed more $\mathrm{N}$ than the highest performing pure stand (RC). However, the amounts of $\mathrm{N}_{2}$-fixation in mixtures containing $\mathrm{RC}$ were comparable to the strongest species in the pure stands and mostly higher than the pure stands of $\mathrm{WC}$ and $\mathrm{LU}$ and the $\mathrm{WC}+\mathrm{LU}$ mixture. Hence, the lower amount of $\mathrm{N}_{2}$-fixed in the $\mathrm{WC}$ and $\mathrm{LU}$ pure stands and in the $\mathrm{WC}+\mathrm{LU}$ mixture was compensated when $\mathrm{RC}$ was incorporated in the seed mixture, at least in a relatively small proportion. Thus, our study showed that forage legumes have the potential to deliver a high herbage production, $\mathrm{N}$ accumulation and $\mathrm{N}_{2}$-fixation, and provide protein-rich biomass without the need for $\mathrm{N}$ fertilization. These perennial crops are therefore a strong tool in the challenge of increasing European protein self-sufficiency. In addition, mixtures of perennial legumes might be more stable in their biomass yields and amount of $\mathrm{N}_{2}$-fixed when measured across more than one growing season- an aspect that calls for further research since it was not included in the present study.

\section{Conclusions}

Our study showed that mixtures of forage legume species had high biomass productivity and $\mathrm{N}$ yield from $\mathrm{N}_{2^{-}}$ fixation. The proportion of $\mathrm{N}$ derived from $\mathrm{N}_{2}$-fixation, and soil $\mathrm{N}$ uptake in most cases, in the mixtures was similar to that of the respective pure stands; hence, we did not observe a mixture effect on $\mathrm{N}_{2}$-fixation as known from mixtures of legumes and non-legumes. Red clover was highly competitive under the study conditions, and there was no indication of complementary resource use in red clover-dominated mixtures. We conclude that mixtures consisting of only forage legume species do not express strong complementarity or overyielding. However, such mixtures can be grown without compromising herbage production, $\mathrm{N}$ accumulation and input of $\mathrm{N}$ from $\mathrm{N}_{2}$-fixation, provided that the mixture contains the dominant species (red clover in the present study) at least as a small proportion in the seed mixture.

Acknowledgements This work was funded by the Green Development and Demonstration Program (GUDP project MultiPlant) as part of the Organic RDD -2 programme, and coordinated by the International Centre for Research in Organic Food Systems (ICROFS). We thank the staff at Foulumgård experimental station for technical assistance and Margit Schacht (Aeces.dk) for proofreading.

\section{References}

Anglade J, Billen G, Garnier J (2015) Relationships for estimating $\mathrm{N}_{2}$ fixation in legumes: incidence for $\mathrm{N}$ balance of legumebased cropping systems in Europe. Ecosphere 6:1-24

Barber L, Joern B, Volenec J, Cunningham S (1996) Supplemental nitrogen effects on alfalfa regrowth and nitrogen mobilization from roots. Crop Sci 36:1217-1223

Black AD, Laidlaw A, Moot D, O'Kiely P (2009) Comparative growth and management of white and red clovers. Irish J Agr Food Res 48:149-166

Bouxin A (2014) Food and feed statistical year book 2014. FEFAC, European feed manufactures federation', Brussels, Belgium (http://www.Fefac.Eu/files/65464.Pdf. Accessed on 16 Sept 2016)

Burchill W, James EK, Li D, Lanigan GJ, Williams M, Iannetta PPM, Humphreys J (2014) Comparisons of biological nitrogen fixation in association with white clover (Trifolium repens $\mathrm{L}$.) under four fertiliser nitrogen inputs as measured using two ${ }^{15} \mathrm{~N}$ techniques. Plant Soil 385(1-2):287-302

Carlsson G, Huss-Danell K (2003) Nitrogen fixation in perennial forage legumes in the field. Plant Soil 253:353-372

Carlsson G, Huss-Danell K (2014) Does nitrogen transfer between plants confound ${ }^{15} \mathrm{~N}$-based quantifications of $\mathrm{N}_{2}$ fixation? Plant Soil 374:345-358

Carlsson G, Palmborg C, Jumpponen A, Scherer-Lorenzen M, Högberg P, Huss-Danell K (2009) $\mathrm{N}_{2}$ fixation in three perennial Trifolium species in experimental grasslands of varied plant species richness and composition. Plant Ecol 205:87-104

Carlsson G, Mårtensson LM, Prade T, Svensson SE, Jensen ES (2017) Perennial species mixtures for multifunctional production of biomass on marginal land. GCB Bioenergy 9:191-201 
Chalk PM, Inácio CT, Balieiro FC, Rouws JR (2016) Do techniques based on ${ }^{15} \mathrm{~N}$ enrichment and $15 \mathrm{~N}$ natural abundance give consistent estimates of the symbiotic dependence of N2fixing plants? Plant Soil 399:415-426

Core Team R (2016) R: a language and environment for statistical computing. In: $\mathrm{R}$ foundation for statistical computing. Austria. URL, Vienna https://www.R-project.org/

Dhamala NR, Rasmussen J, Carlsson G, Søegaard K, Eriksen J (in press) $\mathrm{N}$ transfer in three-species grass-clover mixtures with chicory, ribwort plantain or caraway. Plant Soil. doi:10.1007 /s11104-016-3088-6

Elgersma A, Søegaard K (2016) Effects of species diversity on seasonal variation in herbage yield and nutritive value of seven binary grass-legume mixtures and pure grass under cutting. Eur J Agron 78:73-83

Eriksen J, Askegaard M, Søegaard K (2008) Residual effect and nitrate leaching in grass-arable rotations: effect of grassland proportion, sward type and fertilizer history. Soil Use Manage 24:373-382

Fowler D, Coyle M, Skiba U, Sutton MA, Cape JN, Reis S, Sheppard LJ, Jenkins A, Grizzetti B, Galloway JN (2013) The global nitrogen cycle in the twenty-first century. Phil Trans R Soc B 368:20130164

Frame J (2005) Forage legumes for temperate grasslands. Rome: food and agriculture organization of the United Nations. Science Publishers, Inc., Plymouth, pp 101-115, 200-224

Frankow-Lindberg B, Dahlin AS (2013) $\mathrm{N}_{2}$ fixation, $\mathrm{N}$ transfer, and yield in grassland communities including a deep-rooted legume or non-legume species. Plant Soil 370:567-581

Fustec J, Lesuffleur F, Mahieu S, Cliquet JB (2010) Nitrogen rhizodeposition of legumes. A review. Agron Sustain Dev 30: $57-66$

Glover JD, Culman SW, DuPont ST, Broussard W, Young L, Mangan ME, Mai JG, Crews TE, DeHaan LR, Buckley DH (2010) Harvested perennial grasslands provide ecological benchmarks for agricultural sustainability. Agric Ecosyst Environ 137:3-12

Hector A (1998) The effect of diversity on productivity: detecting the role of species complementarity. Oikos 82:597-599

Høgh-Jensen H, Schjoerring JK (2000) Below-ground nitrogen transfer between different grassland species: direct quantification by ${ }^{15} \mathrm{~N}$ leaf feeding compared with indirect dilution of soil ${ }^{15}$ N. Plant Soil 227:171-183

Jacot KA, Lüscher A, Nösberger J, Hartwig UA (2000) Symbiotic $\mathrm{N}_{2}$ fixation of various legume species along an altitudinal gradient in the Swiss alps. Soil Biol Biochem 32:1043-1052

Kelner DJ, Vessey JK, Entz MH (1997) The nitrogen dynamics of 1-, 2-and 3-year stands of alfalfa in a cropping system. Agric Ecosyst Environ 64:1-10

Kirwan L, Lüscher A, Sebastia M, Finn J, Collins R, Porqueddu C, Helgadottir A, Baadshaug O, Brophy C, Coran C (2007) Evenness drives consistent diversity effects in intensive grassland systems across 28 European sites. J Ecol 95:530-539

Louarn G, Pereira-Lopès E, Fustec J, Mary B, Voisin AS, de Faccio Carvalho PC, Gastal F (2015) The amounts and dynamics of nitrogen transfer to grasses differ in alfalfa and white cloverbased grass-legume mixtures as a result of rooting strategies and rhizodeposit quality. Plant Soil 389:289-305

Lüscher A, Mueller-Harvey I, Soussana JF, Rees R, Peyraud JL (2014) Potential of legume-based grassland-livestock systems in Europe: a review. Grass Forage Sci 69:206-228
Nyfeler D, Huguenin-Elie O, Suter M, Frossard E, Lüscher A (2011) Grass-legume mixtures can yield more nitrogen than legume pure stands due to mutual stimulation of nitrogen uptake from symbiotic and non-symbiotic sources. Agric Ecosyst Environ 140:155-163

Palmborg C, Scherer-Lorenzen M, Jumpponen A, Carlsson G, Huss-Danell K, Högberg P (2005) Inorganic soil nitrogen under grassland plant communities of different species composition and diversity. Oikos 110:271-282

Phelan P, Moloney A, McGeough E, Humphreys J, Bertilsson J, O'Riordan E, O'Kiely P (2015) Forage legumes for grazing and conserving in ruminant production systems. Crit Rev Plant Sci 34:281-326

Pirhofer-Walzl K, Rasmussen J, Høgh-Jensen H, Eriksen J, Søegaard K, Rasmussen J (2012) Nitrogen transfer from forage legumes to nine neighbouring plants in a multispecies grassland. Plant Soil 350:71-84

Rasmussen J, Søegaard K, Pirhofer-Walzl K, Eriksen J (2012) $\mathrm{N}_{2^{-}}$ fixation and residual $\mathrm{N}$ effect of four legume species and four companion grass species. Eur J Agron 36:66-74

Rasmussen J, Gylfadóttir T, Loges R, Eriksen J, Helgadóttir Á (2013) Spatial and temporal variation in $\mathrm{N}$ transfer in grasswhite clover mixtures at three northern European field sites. Soil Biol Biochem 57:654-662

Roscher C, Thein S, Schmid B, Scherer-Lorenzen M (2008) Complementary nitrogen use among potentially dominant species in a biodiversity experiment varies between two years. J Ecol 96:477-488

Sanderson M, Soder K, Muller L, Klement K, Skinner R, Goslee S (2005) Forage mixture productivity and botanical composition in pastures grazed by dairy cattle. Agron J 97:1465-1471

Schulze J (2004) How are nitrogen fixation rates regulated in legumes? J Plant Nutr Soil Sci 167:125-137

Solati Z, Jørgensen U, Eriksen J, Søegaard K (2017) Dry matter yield, chemical composition and estimated extractable protein of legume and grass species during the spring growth. J Sci Food Agric. doi:10.1002/jsfa.8258

Thompson L, Harper JL (1988) The effect of grasses on the quality of transmitted radiation and its influence on the growth of white clover Trifolium repens. Oecologia 75:343-347

Tilman D, Hill J, Lehman C (2006) Carbon-negative biofuels from low-input high-diversity grassland biomass. Science 314 : $1598-1600$

Tomm GO, Walley FL, van Kessel C, Slinkard AE (1995) Nitrogen cycling in an alfalfa and bromegrass sward via litterfall and harvest losses. Agron J 87:1078-1085

Unkovich M, Herridge D, Peoples M, Cadisch G, Boddey B, Giller K, Alves B, Chalk P (2008) Measuring plantassociated nitrogen fixation in agricultural systems. Australian Centre for International Agricultural Research (ACIAR), Canberra, Australia, pp 131-188

Wichern F, Eberhardt E, Mayer J, Joergensen RG, Müller T (2008) Nitrogen rhizodeposition in agricultural crops: methods, estimates and future prospects. Soil Biol Biochem 40:30-48

Wolf DD, Smith D (1964) Yield and persistence of several legume-grass mixtures as affected by cutting frequency and nitrogen fertilization. Agron J 56:130-133

Younie D (2012) Grassland management for organic farmers. The Crowood Press, Marlborough, pp 18-33 